\title{
Effect of lead in the aerobic decomposition of Myriophyllum aquaticum (Vellozo) Verdecourt
}

\author{
Soares, B.S., Cunha-Santino, M.B. \& Bianchini JR., I. \\ Departamento de Hidrobiologia, Universidade Federal de São Carlos (UFSCar). Rodovia Washington Luiz, km 235. \\ São Carlos (SP), CEP: 13565-905. Brasil.
}

Received April 08, 2019; Accept August 31, 2020

\begin{abstract}
Lead is a toxic element that has been used since early times and is still employed today in several industrial processes. Events as the collapse of the Fundão dam in Bento Rodrigues, district of Mariana (MG) on November 2015, significantly increase concentrations of metals above-recommended levels, including lead. In this context, this study aims to evaluate the impact of lead in the cycling rate of organic matter in the aquatic environment. Thus, the rates of aerobic decomposition of Myriophyllum aquaticum (Vell.) Verdec at different concentrations of lead (5.0, 10.0, 20.0 and $30.0 \mathrm{mg} \mathrm{L}^{-1}$ ) were measured, analyzing the dissolved oxygen consumption. Decomposition chambers filled with samples of water and M. aquaticum were incubated at $20^{\circ} \mathrm{C}$ in the dark for 80 days and periodically had the oxygen concentrations determined by polarography, when the concentrations were less than $2 \mathrm{mg} \mathrm{L}^{-1}$, the incubations were re-aerated. At the lowest concentrations (5.0 and $\left.10.0 \mathrm{mg} \mathrm{L}^{-1}\right)$ of lead the mineralization was lower, however, the reaction coefficients and the amount of oxygen consumed were equivalent to the control. At the highest concentrations $\left(20.0\right.$ and $\left.30.0 \mathrm{mg} \mathrm{L}^{-1}\right)$ the mineralization was increased, with the reduction of reaction coefficients and higher oxygen consumption.
\end{abstract}

Keywords: aquatic macrophytes; contamination, oxygen uptake; metal; mathematical modeling.

\section{INTRODUCTION}

Heavy metals and others elements may correspond to trace elements in biochemical reactions, but when present in large quantities in the cells they form nonspecific complex compounds (Nies, 1999), they have the capability to undergo bioaccumulation and biomagnification processes (Salgado et al., 2018) and all enzyme systems are potentially susceptible to metal toxicity (Moreira \& Moreira, 2004). Most of these metals are transitional elements and do not have a complete $\mathrm{d}$ orbital, allowing the formation of cations able of creating complex compounds that may or may not participate in oxidereduction reactions (Nies, 1999). Cations of heavy metals, especially those with high atomic numbers, tend to bind to -SH groups (sulfhydryl group) and may inhibit the activity of bound enzymes, for example, the oxidative phosphorylation or interact with ions such as $\mathrm{Cd}^{2+}, \mathrm{Zn}^{2+}, \mathrm{Ca}^{2+}, \mathrm{Ni}^{2+}, \mathrm{Co}^{2+}, \mathrm{Fe}^{2+}$ or $\mathrm{Mg}^{2+}$, thus inhibiting their physiological functions (Nies, 1999). Metals are predominantly soluble in the ionic form or chelates of organometallic compounds and their solubility in water allows the absorption by the organisms (Sigg, 1985; Landis \& Yu, 2003).

Lead has been used for a long time; there are indications of its use 7000 years ago by the Egyptians (Hoffman, 1995). Some historians believe that the intoxication of the aristocracy by lead may have been responsible for the destruction of the Roman culture (Hoffman, 1995) since it was used as a wine sweetener (lead acetate) in water pipes and kitchen containers (Baird, 2007). The entrance of lead in aquatic environments is due to atmospheric deposition, sewage discharges and direct industrial and mine discharges, soil leachate, mine tailing, highway runoff, and lead plumbing systems (Hoffman, 1995). In these environments the lead can be found in the sediments as in the aqueous portion, this depends on the $\mathrm{pH}$ and salts

*Corresponding author: Beatriz Segnini Soares; e-mail: beasegninisoares@gmail.com 
dissolved and organic complexing agents present (Azevedo \& Chasin, 2003). In surface water lead can be found complexed with organic compounds, such as humic or fulvic acids (Azevedo \& Chasin, 2003).

Events such as the disruption of the Fundão tailing containment dam in the Bento Rodrigues district in Mariana (Minas Gerais State, Brazil) on November 5, 2015, where about $50-60$ million $\mathrm{m}^{3}$ of sludge was dumped, significantly increase the concentrations of metals above recommended levels in Doce River, including lead (Carvalho et al., 2017). The dam rupture ended up transporting large quantities of trace elements and sediment over long distances, in the case of Mariana, 74 million tons were transported in the fourteen months following the disruption while they were to be 2.5 million tons (Magris et al., 2019). Despite of not being considered toxic, the mud affected the quality of the soils (Guerra et al., 2017), the benthic community (Gomes, et al. 2017), macrophyte growth (Bottino et al., 2017) and water quality along the river (Hatje et al., 2017), besides losses in fishing, energy generation, and water supply (Burton \& Nedric, 2017). The concentration of $\mathrm{Pb}$ found in the soil was $20.2 \pm 4.6 \mathrm{mg} \mathrm{kg}^{-1}$ being mainly associated with oxyhydroxides of iron (Queiroz et al., 2018); in the Doce River basin, there were rivers stretches where the maximum concentration of $\mathrm{Pb}$ were $1.0 \mathrm{mg} \mathrm{L}^{-1}$ (IGAM, 2017). In these aquatic environments, macrophytes can play an important role in maintaining ecosystem services, such as nutrient cycling, pollutant retention and biodiversity conservation (Lacoul \& Freedman, 2006). These plants affect the physical and chemical characteristics of water and sediment, being a source of organic matter, modifying the spatial structure of the ecosystem and participating in the cycling of nutrients, changing the dynamics of nutrients and communities such as creating habitats for fish, affecting the phytoplankton community (Thomaz \& Cunha, 2010; Thomaz \& Esteves, 2011). Coarse particulate organic matter derived from macrophytes decomposition can be important source of energy and nutrients in continental aquatic ecosystems (Moore et al., 2004).

Owing the interactions of lead in living beings as mentioned, and consequently in the functioning of ecosystems (aquatic and terrestrial), and the importance of macrophytes to aquatic environments, this study aims to evaluate the effect of $\mathrm{Pb}$ on the aerobic decomposition of aquatic plants detritus, a fundamental process for the energy flow and for the maintenance of the metabolism of aquatic ecosystems under similar conditions to those of environmental accidents (Doce River). For this purpose, the macrophyte species Myriophyllum aquaticum (Vell.) Verdec was selected as organic matter resource, observing whether there would be a negative effect on the metabolic activity of the decomposing microorganisms (e.g., oxygen consumption). Due to the interference of $\mathrm{Pb}$ in biochemical routes of microorganisms, it is assumed that lead toxicity will prejudice aerobic decomposition, which should be explained by the decrease in oxygen consumption coefficients and altered accumulated oxygen consumption.

\section{MATERIALS AND METHODS}

The water and macrophyte samplings were carried out at the Monjolinho Reservoir located at the Federal University of São Carlos, São Carlos, SP, Brazil (21 ${ }^{\circ} 59^{\prime} \mathrm{S}$ and $47^{\circ} 52^{\prime}$ W). It is a small (ca. $4.69 \mathrm{ha}$ ) and shallow (average depth of $1.5 \mathrm{~m}$ ) artificial environment located in the subtropical region (Santos et al., 2009). With two annual climatic regimes, the dry season between April and September, and the warm rainy season between October and March according to Köppen's systematic (Cwb) (Köppen, 1931). The retention time depends on these seasons and varies from 2.1 to 22.9 days (Santos et al., 2009). According to Santos et al. (2011), the lacustrine region of the reservoir is characterized by an annual average of suspended material of $48.8 \pm 10.3 \mathrm{mg} \mathrm{L}^{-1}, 11.9 \pm 10.7 \mathrm{NTU}$ of turbidity, mean average temperature of $20.6 \pm 3.3{ }^{\circ} \mathrm{C}$, and dissolved oxygen of $6.9 \pm 0.8 \mathrm{mg} \mathrm{L}^{-1}$. The $\mathrm{pH}$ was neutral $(6.7 \pm 0.3)$ and the electrical conductivity was $41.6 \pm 5.1$. The concentration of dissolved inorganic carbon was $4.6 \pm 1.3 \mathrm{mg}$ $\mathrm{L}^{-1}$ and organic was $2.4 \pm 1.1 \mathrm{mg} \mathrm{L}^{-1}$.

The macrophyte used in this study due to its presence in the Monjolinho reservoir was Myriophyllum aquaticum (Vellozo) Verdecourt (Haloragaceae), a genus with many species (ca. 68 species) of the aquatic core-eudicots (Silva et al., 2011). Known as parrotfeather, this plant occurred in stagnant or slow environment that may or may not be rooted (Silva et al., 2011). Native to the plains of central South America but has been widely distributed due to its use in aquarism and is considered invasive in several regions, which is facilitated by the high capacity of regeneration of its fragments (Francis, 2012).

The proposed decomposition experiments were adapted from the biochemical oxygen demand tests (BOD). Thus, through oxygen consumption by cellular respiration (e.g., $\mathrm{C}_{6} \mathrm{H}_{12} \mathrm{O}_{6}+6 \mathrm{O}_{2} \Rightarrow 6 \mathrm{CO}_{2}+6 \mathrm{H}_{2} \mathrm{O}$ ), thus, it was possible to estimate indirectly the quantity of labile organic matter consumed. This value was calculated by the difference between the initial and final dissolved oxygen concentrations of the sample (Valente et al., 1997). To prepare the experiment, the water $(\approx 10$ liters $)$ was filtered with a cellulose acetate membrane (pore $\varnothing=0.45 \mu \mathrm{m}$, Millipore). The collected macrophytes were washed to remove the periphyton and sediment particles adhered; then, the plants were dehydrated $\left(40{ }^{\circ} \mathrm{C}\right)$, until constant mass. The $\mathrm{C}$ contents of the plant tissues, at the beginning of the experiment, were determined by TOC analyzer (Shimadzu, model SSM-5000A).

The sample water was separated into 24 BOD bottles (ca. $300.0 \mathrm{ml}$ ), 6 of them with only water to measure the oxygen consumption due to the decomposition of the dissolved organic matter and eventual phytoplankton cells. In another 6 flasks, samples of water and macrophyte $(100.0 \mathrm{mg}$, dry mass basis, $\mathrm{DM})$ were placed. In the remaining bottles, $100.0 \mathrm{mg}(\mathrm{DM})$ of the macrophyte was added and at different concentrations of lead $\left(5.0,10.0,20.0,30.0 \mathrm{mg} \mathrm{L}^{-1}\right)$ chosen to simulate the scenario of $\mathrm{Pb}$ contamination accidents. After, the flasks were aerated (ca. 3 hours), and then, incubated at $20^{\circ} \mathrm{C}$; near the 
annual temperature average of the reservoir (Santos et al.; 2011), in the dark, in order to avoid the phytoplanktonic photosynthesis. Periodically, the concentrations of dissolved oxygen were determined by polarography (oximeter, YSI model 58), and when concentrations were close to $2.0 \mathrm{mg} \mathrm{L}^{-1}$, the incubations were re-aerated again.

After the incubation time ( 80 days) the contents of the chambers were filtered through cellulose acetate membrane (pore $\varnothing=0.45 \mu \mathrm{m}$; Millipore). The particulate fractions were incinerated at $550^{\circ} \mathrm{C}$ (two hours) in order determinate the particulate organic matter (POM) and then, those values were multiplied by factor of 0.465 (Santos et al., 2009) to estimate the carbon content (POC). The final concentrations of dissolved carbon were determined by the TOC analyzer (Shimadzu model TOC-L).

Initially, it was assumed that the time consumption of oxygen was defined by first-order kinetics (Equations 1 to 8), as in the BOD tests (Borsuk \& Stow, 2000; Davis \& Cornwell, 2008).

$$
\frac{d L_{t}}{d t}=-k L_{t}
$$

where $L t=$ oxygen uptake at time $\mathrm{t}\left(\mathrm{mg} \mathrm{L}^{-1}\right) ; k=$ deoxygenation rate constant $\left(\mathrm{d}^{-1}\right)$.

Rearranging Equation 1 and integrating results:

$$
\begin{aligned}
& \frac{d L_{t}}{L_{t}}=-k d t \\
& \int_{L_{0}}^{L} \frac{d L_{t}}{L t}=-k \int_{0}^{t} d t \\
& \ln \frac{L_{t}}{L_{0}}=-k t \\
& L_{t}=L_{0} \times e^{-k t} \\
& O C=L_{0}-L_{t} \\
& O C=L_{0}-L_{0} \times e^{-k t} \\
& O C=O C \max \times\left(1-e^{-k t}\right)
\end{aligned}
$$

where: $O C=$ oxygen consumption $(\mathrm{mg})$; $O C \max =$ maximum oxygen consumption $(\mathrm{mg}) ; e=$ base of natural logarithm; $t=$ time (day).

The daily rates of dissolved oxygen consumption were integrated and the kinetic parameters (OCmax and $k$ ) were determined. For this, the curve fits were made through non-linear regressions, using Levemberg-Marquardt's iterative algorithm (Press et al., 2007). The accumulated oxygen consumption was subjected to the normality test and, in sequence, data were compared by the KruskalWallis test, followed by Dunn's Multiple Comparison Test, since the values of oxygen consumption exhibit a non-normal distribution. A level of $\mathrm{P}<0.05$ was adopted in all comparisons.
The percentage of mineralized carbon (MC) in each treatment was calculated as follows:

$$
M C=P O C i-(P O C f+D O C f)
$$

where: $\mathrm{MC}=$ mineralized carbon $(\%) ; \mathrm{POCi}=$ initial particulate organic carbon $(\mathrm{mg}) ; \mathrm{POCf}=$ final particulate organic carbon (mg); DOCf = final dissolved organic carbon (mg).

The calculation of mineralized dissolved organic carbon (MCOD) was performed with the following equation:

$$
M D O C=\frac{[(P O C i * 0.037)-D O C f] * 100}{P O C i * 0,037}
$$

where: $\mathrm{MCOD}=$ mineralized dissolved organic carbon (\%); POCi = initial particulate organic carbon (mg); DOCf = final dissolved organic carbon $(\mathrm{mg}) ; 0.037=$ approximate fraction of dissolved organic carbon (Grando, 2018).

For the calculation of the mineralization coefficient $(\mathrm{km})$ was used:

$$
k_{m}=\frac{\operatorname{Ln}(M C / 100)}{t}
$$

where: $\mathrm{km}=$ mineralization coefficient $\left(\right.$ day $\left.^{-1}\right) ; \mathrm{MC}=$ mineralized carbon $(\%) ; t=$ time (day).

\section{RESULTS}

The accumulated oxygen consumption only of the water samples of the reservoir were ca. $11.0 \mathrm{mg} \mathrm{L}^{-1}$, thus, for all treatments (Figure 1), this value was subtracted before the transformation of oxygen consumption per $g$ of plant dry weight. The results of accumulated oxygen consumption of the experiments, in general, showed higher consumption in the beginning of the experiment (ca. 10 days). Then, they decreased and maintained between 0.0 and $5.0 \mathrm{mg} \mathrm{L}^{-1}$ per day in the control and between 0.0 and $10.0 \mathrm{mg} \mathrm{L}^{-1}$ per day in the treatments with $\mathrm{Pb}$.

The statistical tests showed that the oxygen consumption in the control was equivalent to the treatments with 5.0, 10.0, and $30.0 \mathrm{mg} \mathrm{L}^{-1}$ of $\mathrm{Pb}$, whereas the incubation with 20.0 $\mathrm{mg} \mathrm{L} \mathrm{L}^{-1}$ of $\mathrm{Pb}$ was different from all the others treatments $(\mathrm{p}$ $<0.001$ ). By fitting the oxygen consumption curves, it was possible to observe that in high concentrations of lead there was an increase in the oxygen consumption demonstrated by the increase of the OCmax and a tendency to decrease the values of the oxygen consumption coefficient.

In the lower concentrations of $\mathrm{Pb}\left(5.0\right.$ and $\left.10.0 \mathrm{mg} \mathrm{L}^{-1}\right)$ there was a decrease in the yield of mineralized carbon (MC) evidenced by the decrease global coefficient of mineralization of organic carbon $(\mathrm{km})$; Table 1. At the highest concentrations of $\mathrm{Pb}\left(20.0\right.$ and $\left.30.0 \mathrm{mg} \mathrm{L}^{-1}\right)$ there was an increase in the percentage of mineralized carbon and this process was faster than the control itself. There was a gradual increase in DOC mineralization with increasing $\mathrm{Pb}$ concentration, at $20.0 \mathrm{mg}$ $\mathrm{L}^{-1}$ concentration it was 6.23 times faster than the control and at $30.0 \mathrm{mg} \mathrm{L}^{-1}$ it was 4.76 . 
According to the (linear) relationship between OCmax and mineralized carbon (Figure 2), the angular coefficient pointed out that 3.052 molecules of oxygen were used for each atom of mineralized carbon.

\section{DISCUSSION}

The toxicity of lead is explained by its action in fundamental biochemical processes, since it is able to: i) inhibit or mimic calcium, competing in several biochemical processes such as, the activation of calmodulin involving binding with carboxyl groups and in mitochondrial respiration; ii) interfering with the functioning of cell membranes; iii) restrains or stimulate proteins due to the formation of stable complexes with ligands capable of donating electrons such as oxygen $(-\mathrm{OH})$, nitrogen
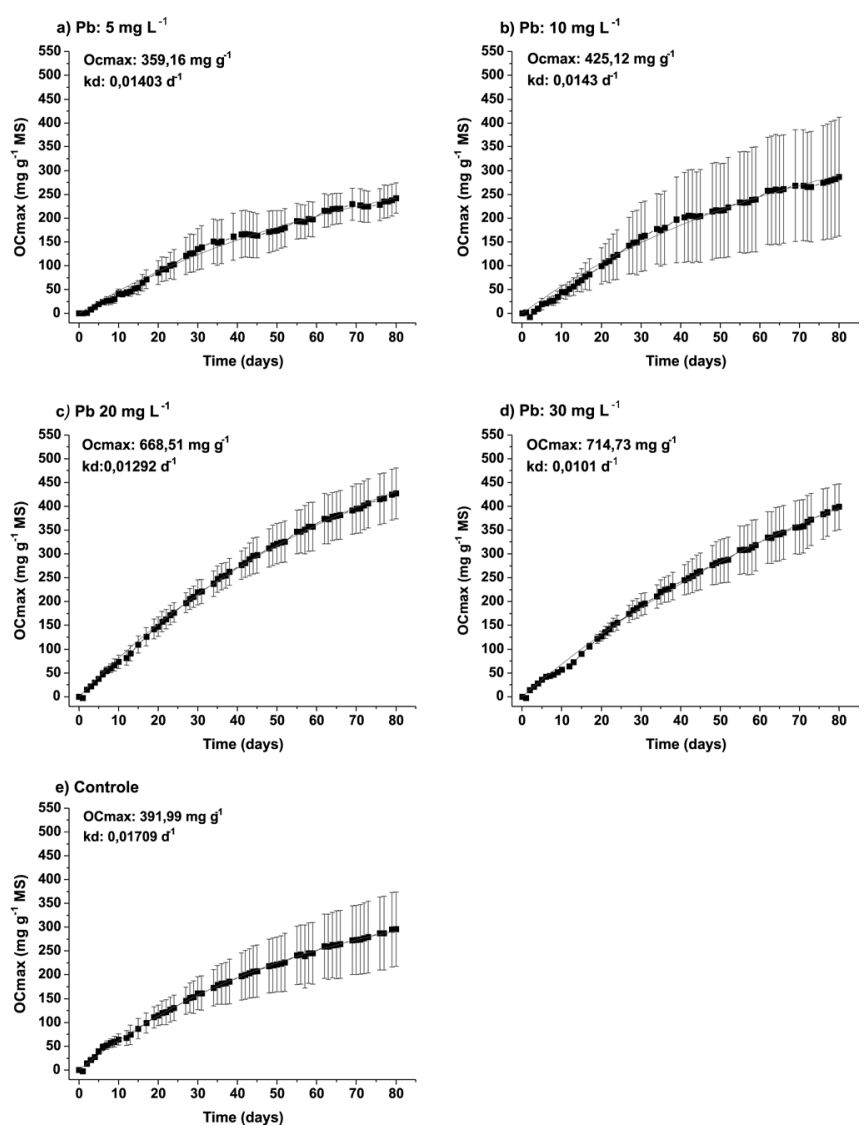

Figure 1. Kinetics of accumulated oxygen consumption owing to the aerobic mineralization of Myriophyllum aquaticum.
$\left(-\mathrm{NH}_{2}\right)$, phosphorus $\left(-\mathrm{H}_{2} \mathrm{PO}_{3}\right)$ and sulfur $(-\mathrm{SH})$, which in this case is bound with the activation of the protein kinase C (Moreira \& Moreira, 2004) and iv) reduces the ability of t-RNA to bind to ribosomes (Landis \& Yu, 2003). Overall, these biochemical processes interfere with the microbial metabolism (Roane et al., 2009) and consequently, in the cycling of elements in the aquatic environments.

The detritus of the macrophytes is predominantly composed of refractory organic matter and due to this, the mass decrease observed in these experiments is basically related to the aerobic mineralization of the labile fractions (particulate or dissolved) and consequently to oxygen consumption (Bianchini Jr. et al., 2011). According to decomposition experiments, it was verified that three possible routes of mineralization occur in the aerobic decomposition: i) the rapid oxidation of the labile compounds, that is, it has a short half-life; ii) leaching and catabolism of dissolved organic matter (DOM) which normally have an intermediate half-life; iii) oxidation of refractory particulate debris (POM) that have a long half-life (Bianchini Jr., 2003). These routes are influenced by several factors such as the types of metabolism that perform the decomposition, environmental variables such as temperature and dissolved oxygen, among others, the characteristics of the detritus, for example, chemical composition, particle size and forms by which the debris is adduced or generated (Bianchini Jr., 2003).

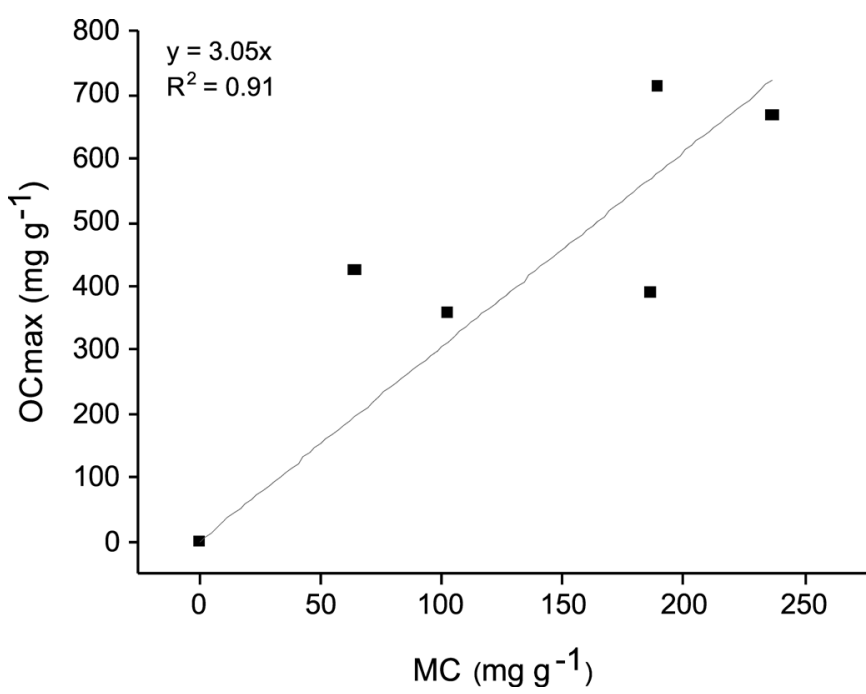

Figure 2. Relationship between maximum oxygen consumption (OCmax) and mineralized carbon (MC) from aerobic decomposition of Myriophyllum aquaticum.

Table 1. Parameters of Myriophyllum aquaticum aerobic mineralization; where: i) initial and final particulate organic carbon (POCi and POCf, respectively); ii) final dissolved organic carbon (DOCf); iii) carbon mineralized (MC); iv) mineralization coefficient (km); v) half-life of M. aquaticum mineralization ( $\mathrm{t} / 2$ ); vi) dissolved organic carbon mineralized (MDOC), DOC mineralization rate constant (km DOC); vii) half-life of DOC mineralization ( $\left.\mathrm{t}^{1} / 2\right)$.

\begin{tabular}{lccccccccc}
\hline $\begin{array}{l}\mathbf{P b} \\
(\mathbf{m g ~ L}\end{array}$ & $\begin{array}{c}\text { POCi } \\
(\mathbf{m g})\end{array}$ & $\begin{array}{c}\text { POCf } \\
(\mathbf{m g})\end{array}$ & $\begin{array}{c}\text { DOCf } \\
(\mathbf{m g})\end{array}$ & $\mathbf{M C} \mathbf{( \% )}$ & $\begin{array}{c}\mathbf{k m} \\
\left(\mathbf{d}^{-1}\right)\end{array}$ & $\begin{array}{c}\mathbf{t}^{\mathbf{1}} / \mathbf{2} \\
(\mathbf{d})\end{array}$ & $\begin{array}{c}\text { MDOC } \\
(\mathbf{\%})\end{array}$ & $\begin{array}{c}\mathbf{k}_{\mathrm{M}} \mathbf{D O C} \\
\left.\mathbf{( d}^{-\mathbf{1}}\right)\end{array}$ & $\begin{array}{c}\mathbf{t}^{\mathbf{1} / 2} \\
(\mathbf{d})\end{array}$ \\
\hline 0.0 & 40.65 & 21.59 & 1.078 & 44.34 & 0.0073 & 94.6 & 28.32 & 0.0042 & 166.5 \\
5.0 & 39.22 & 28.77 & 0.911 & 24.32 & 0.0035 & 199.0 & 37.23 & 0.0058 & 119.1 \\
10.0 & 38.62 & 31.89 & 0.849 & 15.24 & 0.0021 & 335.4 & 40.61 & 0.0065 & 106.4 \\
20.0 & 40.86 & 17.68 & 0.189 & 56.31 & 0.0104 & 67.0 & 87.50 & 0.0260 & 26.7 \\
30.0 & 40.57 & 22.08 & 0.308 & 45.05 & 0.0075 & 92.6 & 79.50 & 0.0198 & 35.0 \\
\hline
\end{tabular}


The parameters of oxygen consumption, regardless of the type of macrophyte, are derived from the qualitative characteristics of the plant tissues (such as Myriophyllum aquaticum biomass), as well as the proportion of each fraction of organic matter (Bianchini Jr., 2003). The high oxygen consumption in the first days (Figure 1) can be explained by the consumption of the labile-soluble portion $(23.76 \%)$ of the organic matter and gradually decreased due to the predominance of the mineralization of the refractory fraction (76.24\%) of the macrophyte (Bianchini Jr. et al., 2011).

Experiment with macrophytes from an oligo-mesotrophic reservoir showed that the amount of oxygen used in the degradation ranged from $205.0 \mathrm{mg} \mathrm{g}^{-1}$ (Eleocharis $\mathrm{sp}$ ) to $533.0 \mathrm{mg} \mathrm{g}^{-1}$ (Ludwigia sp); overall, the values of OCmax obtained in our study were within this recorded range. However, in the experiment with macrophytes of the Piraju Reservoir (Bianchini Jr. et al., 2011), the mineralization of Myriophyllum aquaticum presented much lower value (290.0 $\mathrm{mg} \mathrm{g}^{-1}$ ) than was observed in our results. The value of OCmax from the control incubation was probably higher due to the trophic state of the Monjolinho reservoir (eutrophic; Santos et al., 2011) that favored the degradation of the detritus (Viaroli \& Christian, 2004).

Observing the data in Figure 1, the decrease of kd and increase of the OCmax identified in the two treatments with the highest concentration of $\mathrm{Pb}\left(20.0\right.$ and $\left.30.0 \mathrm{mg} \mathrm{L}^{-1}\right)$; indicated that the presence of lead led to decreased reaction rates (i.e., lower speed) and increase in the amount of oxygen consumed. In that case, without the presence of lead, it was estimated that they were oxidized ca. $35 \%$ of the plant carbon. If the stoichiometry ratio (3.052; Figure 2) was maintained, the addition of lead increased the carbon oxidation to $30.01 \%$ $\left(\mathrm{Pb}: 5.0 \mathrm{mg} \mathrm{L}^{-1}\right), 36.07 \%\left(\mathrm{~Pb}: 10.0 \mathrm{mg} \mathrm{L}^{-1}\right), 53.60 \%(20.0 \mathrm{mg}$ $\left.\mathrm{L}^{-1}\right)$ and $57.72 \%\left(30.0 \mathrm{mg} \mathrm{L}^{-1}\right)$. It is important to note that the value obtained experimentally was higher than the theoretical value, usually adopted (2.66; Bianchini Jr. et al., 2011) for the calculation of the oxidation of organic matter based on glucose. These changes suggest a probable alteration in the metabolic routes related to the aerobic oxidation of the organic matter. In organisms, the lead can disturb the pathways of oxidative phosphorylation, metabolic reactions by which aerobic organisms synthesize ATP through the transport of electrons by complexes in the mitochondrial membrane (Vallee \& Ulmer, 1972). The catabolism of organic matter may follow three different pathways, the citric acid cycle or Krebs cycle, the glyoxylate cycle, and the pentoses pathway. In the Krebs cycle, the aerobic reactions are able to release ATP through the oxidation of glucose into carbon dioxide and water. The glyoxylate cycle is observed in some microorganisms, in this way Acetyl-CoA condenses with the oxaloacetate forming citrate. The pentoses pathway (or phosphoglycate pathway), is the route where glucose-6-phosphate is oxidized to pentosesphosphate (Nelson \& Cox., 2014).

The amount of oxygen consumed may change due to the metabolic pathway, since there are enzymes in which lead has an inhibitory interaction, such as the pyruvate dehydrogenase complex that transforms pyruvate into Acetyl-CoA and the succinate dehydrogenase responsible for the dehydrogenation of succinate to fumarate, both in the citric acid cycle, glucose-6-phosphate dehydrogenase that dehydrogenates glucose-6-phosphate into 6-phosphoglycate in the pentoses phosphate pathway (Vallee \& Ulmer, 1972; Nelson \& Cox, 2014).

Differences in the OCmax and kd can also be explained due to degradation in a greater or lesser amount of other substances present in the tissues of the macrophyte used (Table 2) as well as monosaccharides (e.g., polyphenols, terpenes, fatty acids), since the composition (Bianchini Jr. et al., 2011).

The method of depletion of the dissolved oxygen (DO) concentrations evaluates the mineralization, indirectly, through the consumption of dissolved oxygen using the following Equation 12 (Bianchini Jr. et al., 2003). Each component has an $\mathrm{O} / \mathrm{C}$ ratio as shown in Table 3.

$$
\mathrm{C}_{x} \mathrm{H}_{2 y} \mathrm{O}_{z}+\left[x+\left(\frac{y-z}{2}\right)\right] \mathrm{O}_{2} \Rightarrow x \mathrm{CO}_{2}+y \mathrm{H}_{2} \mathrm{O}
$$

Besides the decomposition of these substances consume different amounts of oxygen, the catabolism of these generates secondary compounds that interfere in the stoichiometric coefficients since they are also used in the reactions of biosynthesis and energy acquisition (Bianchini Jr. et al., 2011).

Lead also interacts with organic matter (particulate and dissolved) by adsorption, ion exchange reactions or complexation that, in this case, interferes in the geochemistry of the metal ions, changing its dissolution, charge and redox potential. Its connection with humic substances depends not only on the concentration of the metal or organic matter but also on the ionic strength of the ions (Bezerra et al., 2009). Thus, in lower concentrations of lead, the oxygen consumption was similar, probably due to the interaction between organic matter and $\mathrm{Pb}$, attenuating the toxic action of this metal in the microorganism metabolism. Thus, the effective concentrations of lead for the mineralization were smaller than the nominal ones.

The decomposition depends, in addition to abiotic factors, on the organisms responsible for these processes;

Table 2. Composition of Myriophyllum aquaticum (Little, 1979; MartínezYáñez et al., 2018).

\begin{tabular}{lccc}
\hline $\begin{array}{l}\text { Macrophyte } \\
\text { composition }\end{array}$ & \% Dry mass & $\begin{array}{c}\text { Macrophyte } \\
\text { composition }\end{array}$ & \% Dry mass \\
\hline Ash & 17.25 & $\mathrm{~S}$ & 0.40 \\
Crude protein & 22.30 & $\mathrm{Cl}$ & 1.45 \\
Crude fiber & 14.55 & $\mathrm{Na}$ & 0.80 \\
Dry matter & $10.65 \pm 2.13$ & $\mathrm{Mg}$ & 0.75 \\
Organic matter & $88.13 \pm 0.13$ & $\mathrm{~K}$ & 1.90 \\
Hemicellulose & 19.26 & $\mathrm{Mn}$ & 0.50 \\
Cellulose & 15.39 & $\mathrm{Fe}$ & 0.10 \\
Lignin & $5.14 \pm 1.05$ & $\mathrm{P}$ & 0.50 \\
Extract of ether & $4.25 \pm 0.35$ & $\mathrm{SiO}_{2}$ & 2.45 \\
Dry matter & 7.5 & $\mathrm{Ca}^{2}$ & 2.95 \\
\hline
\end{tabular}


Table 3. O/C proportion of some compounds (Marzzoco \& Torres, 1999; CAS, 2019).

\begin{tabular}{lcc}
\hline Compounds & Formula & $\mathrm{O} / \mathrm{C}$ \\
\hline Monosaccharides & $\left(\mathrm{CH}_{2} \mathrm{O}\right) \mathrm{n}$ & 2.7 \\
Glyoxylic acid & $\mathrm{C}_{2} \mathrm{H}_{2} \mathrm{O}_{3}$ & 1.33 \\
Lignin & $\mathrm{C}_{9} \mathrm{H}_{10} \mathrm{O}_{2}, \mathrm{C}_{10} \mathrm{H}_{12} \mathrm{O}_{3}, \mathrm{C}_{11} \mathrm{H}_{14} \mathrm{O}_{4}$ & ca. $3.03-3.11$ \\
Cellulose & $\left(\mathrm{C}_{6} \mathrm{H}_{10} \mathrm{O}_{5}\right) \mathrm{n}$ & 2.66 \\
Palmitic acid & $\mathrm{C}_{16} \mathrm{H}_{32} \mathrm{O}_{2}$ & 3.88 \\
\hline
\end{tabular}

they use specific metabolic pathways that produce different intermediates that interact with other organisms and compounds (Bianchini Jr. et al., 2011). The growth of these organisms during the decomposition conserves carbon in the organic form, which alters the circulation of organic compounds, changing also the stoichiometries relation (Cunha-Santino \& Bianchini Jr., 2002).

Some studies have shown that a significant increase in the concentrations of metals leads to marked responses, thus increasing the resistance of the microorganisms (Roane et al., 2009). This fact may explain the increase in OCmax, $\mathrm{kd}$ and increased mineralization at the highest concentrations (20.0 and $30.0 \mathrm{mg} \mathrm{L}^{-1}$ ), whereas the lowest concentrations (5.0 and $10.0 \mathrm{mg} \mathrm{L}^{-1}$ ) had lower values than the control itself. The response to metal toxicity depends on the type of metal, its concentration on the medium, its availability and the type of microorganism (Baquero \& Negri, 1997). The variability of the mechanisms of resistance of these organisms is derived from the diversity of genotypes and the various selective pressures, and with their large population numbers and genomic diversity, the microorganisms have great adaptability (Muñoz et al., 2012).

Considering the experimental procedures adopted, we found that in lower concentrations of lead, there was a negative effect on the cycling rates of $M$. aquaticum detritus in the aquatic environment. Due to the various types of possible interference (e.g., in catabolic routes, adsorption, selection of microorganisms), the presence of lead promoted changes in reaction rates, as well as in the amount of oxygen consumed. In general, the increase in $\mathrm{Pb}$ concentration tended to increase the amount of oxygen consumption, as well as the DOC mineralization rates.

\section{ACKNOWLEDGEMENTS}

The authors thank Fundação de Apoio à Pesquisa do Estado de São Paulo (FAPESP process n $n^{\circ}$ 17/207221) and Conselho Nacional de Desenvolvimento Científico e Tecnológico (CNPq process $\left.n^{\circ} 305263 / 2014-5\right)$ for the granting of scholarships.

\section{REFERENCES}

AZEVEDO, F. A. \& CHASIN, A. A. M. 2003. Metais: gerenciamento da toxicidade. Publisher Atheneu: São Paulo. 554 p.

BAIRD, C. 2007. Química ambiental. Publisher Bookman: Porto Alegre. $622 \mathrm{p}$.
BAQUERO, F. \& NEGRI, M.-C. 1997. Challenges: Selective compartments for resistant microorganisms in antibiotic gradients. BioEssays, 19 (8): 731-736. http://dx.doi.org/10.1002/ bies.950190814

BEZERRA, P. S. S.; TAKIYAMA, L. R. \& BEZERRA, C. W. B. 2009. Complexação de íons de metais por matéria orgânica dissolvida: modelagem e aplicação em sistemas reais. Acta Amazonica, 39 (3): 639-648. http://dx.doi.org/10.1590/S004459672009000300019

BIANCHINI JR., I. 2003. Modelos de crescimento e decomposição de macrófitas aquáticas. In: THOMAZ, S. M.; BINI, L. M. (eds.). Ecologia e manejo de macrófitas aquáticas. EDUEM: Maringá, pp. 85-126.

BIANCHINI JR., I.; BITAR, A. L.; VERANI, J. R. \& PERET, A. C. 2003. Experimento de mineralização aeróbia para ambientes aquáticos: determinação do número de réplicas. Acta Scientiarum. Biological Sciences, 25 (2): 245 - 251. http://dx.doi.org/10.4025/ actascibiolsci.v25i2.1975

BIANCHINI JR., I.; CUNHA-SANTINO, M. B. \& PANHOTA, R. S. 2011. Oxygen uptake from aquatic macrophyte decomposition from Piraju Reservoir (Piraju, SP, Brazil). Brazilian Journal of Biology, 71 (1): 27-35. http://dx.doi.org/10.1590/S151969842011000100006

BORSUK, M. E. \& STOW, C. A. 2000. Bayesian parameter estimation in a mixed-order model of BOD decay. Water Research, 34 (6): 1830-1836. http://dx.doi.org/10.1016/s00431354(99)00346-2

BOTTINO, F.; MILAN, J. A. M.; CUNHA-SANTINO, M. B. \& BIANCHINI JR., I. 2017. Influence of the residue from an iron mining dam in the growth of two macrophyte species. Chemosphere, 186: 488-494. http://dx.doi.org/10.1016/j. chemosphere.2017.08.030

BURTON JR., G. A. \& NEDRICH, S. M. 2017. Exposures in aquatic ecosystems: the link in risk assessments -a critical perspective. Ecotoxicology and Environmental Contamination, 13 (2): 5-9. https://doi.org/doi: 10.5132/eec.2018.02.02

CARVALHO, M., RIBEIRO, K. D., MOREIRA, R. M. \& ALMEIDA, A. M. 2017. Concentração de metais no rio Doce em Mariana, Minas Gerais, Brasil. Acta Brasiliensis, 1 (3): 37 41. https://doi.org/10.22571/Actabra13201758

CAS (Chemical Abstracts Service, American Chemical Society). Substance Search. Available in: http://www.commonchemistry. org/. Access in: 07/01/2019

CUNHA-SANTINO, M. B. \& BIANCHINI JR., I. 2002. Estequiometria da decomposição aeróbia de galhos, cascas serapilheira e folhas. In: ESPÍNDOLA, E; MAUAD, F. F.; SCHALCH, V.; ROCHA, O.; FELICIDADE, N. \& RIETZLER, A. C. (eds.). Ed. Recursos hidroenergéticos: usos, impactos e planejamento integrado. Rima: São Carlos, pp. 43-56.

DAVIS, M. L. \& CORNWELL, D. A. 2008. Introduction to environmental engineering. McGraw-Hill: Dubuque, 1008 p.

FRANCIS, R. A. (ed.). 2012. A handbook of global freshwater invasive species. New York: Earthscan, $456 \mathrm{p}$.

GOMES, L. E., CORREA, L. B., SÁ, F., NETO, R. R., BERNARDINO, A. F. 2017. The impacts of the Samarco mine tailing spill on the Rio Doce estuary, eastern Brazil. Marine Pollution Bulletin, 120 (1-2): 28-36. https://doi.org/10.1016/j. marpolbul.2017.04.056

GUERRA, M. B. B., TEANEY, B. T., MOUNT, B. J., ASUNSKIS, D. J., JORDAN, B. T., BARKER, R. J., SANTOS, E. E., SCHAEFER, C. E. G. R. 2017. Postcatastrophe analysis of the Fundão tailings dam failure in the Doce River system, southeast Brazil: potentially toxic elements in affected soils. Water, Air, \& Soil Pollution, 228, 252. https:// doi.org/10.1007/s11270-017-3430-5 
GRANDO, M. S. 2018. Mudanças climáticas e ciclagem de carbono na decomposição aeróbia e anaeróbia de Myriophyllum aquaticum (Vellozo) Verdecourt. MSc. Dissertation, Universidade Federal de São Carlos, São Carlos, 91p.

HOFFMAN, D. J. (ed.). 1995. Handbook of ecotoxicology. Lewis Publishers: Boca Raton, 755 p.

HATJE, V., PEDREIRA, R. M. A., REZENDE, C.E., SCHETTINI, C. A. F., SOUZA, G. C., MARIN, D. C., HACKSPACHER, P. C. 2017. The environmental impacts of one of the largest tailing dam failures worldwide. Scientific Reports, 7, 10706. https://doi. org/10.1038/s41598-017-11143-x

IGAM (Instituto Mineiro de Gestão das Águas). 2017. Encarte especial sobre a qualidade das águas do Rio Doce após 2 anos do rompimento de Barragem de Fundão 2015-2017. Belo Horizonte.

KÖPPEN, W. 1931. Grundriss der klimakunde. De Gruyter: Berlin, $388 \mathrm{p}$.

LACOUL, P. \& FREEDMAN, B. 2006. Environmental influences on aquatic plants in freshwater ecosystems. Environmental Reviews, 14(2): 89-136. https://doi.org/10.1139/A06-001

LANDIS, W. G. \& YU, M-H. 2003. Introduction to environmental toxicology: impacts of chemicals upon ecological systems. Lewis Publishers: Boca Raton, 484 p.

LITTLE, E. C. S. 1979. Handbook of utilization of aquatic plants. FAO: Rome, 176 p.

MAGRIS, R. A.; MARTA-ALMEIDA, M.; MONTEIRO, J. A. F. \& BAN, N. C. 2019. A modelling approach to assess the impact of land mining on marine biodiversity: Assessment in coastal catchments experiencing catastrophic events (SW Brazil). Science of The Total Environment, 659: 828-840. https://doi. org/ 10.1016/j.scitotenv.2018.12.238

MARTÍNEZ-YÁÑEZ, A. del R.; ALBERTOS-ALPUCHE, P. J.; GUZMAN-MENDOZA, R.; ROBAINA-ROBAINA, L. E.; ALVAREZ-GONZALEZ, A.; DIAZ-PLASCENCIA, D. 2018. Production and chemical composition of hydrophytes cultivated in aquaponics. Ecosistemas y Recursos Agropecuarios, 5 (14): 247 - 257. https://doi.org/10.19136/era.a5n14.1447

MARZZOCO, A. \& TORRES, B. B. 1999. Bioquímica básica. Guanabara Koogan: Rio de Janeiro, 360 p.

MOORE, J. C.; BERLOW, E. L.; COLEMAN, D. C.; RUITER, P. C.; DONG, Q.; HASTINGS, A.; JOHNSON, N. C; MCCANN, K. S; MELVILLE, K.; MORIN, P. J.; NADELHOFFER, K.; ROSEMOND, A. D.; POST, D. M.; SABO, J. L.; SCOW, K. M.; VANNI, M. J \& WALL, D.H. 2004. Detritus, trophic dynamics and biodiversity. Ecology Letters, 7: 584-600. https:// doi.org/10.1111/j.1461-0248.2004.00606.x

MOREIRA, F. R. \& MOREIRA, J. C. 2004. Os efeitos do chumbo sobre o organismo humano e seu significado para a saúde. Revista Panamericana de Salud Pública, 15 (2): 119-129.

MUÑOZ, A.; RUIZ, E.; ABRIOUEL, H.; GÁLVEZ, A.; EZZOUHRI, L.; LAIRINI, K. \& ESPÍNOLA, F. 2012. Heavy metal tolerance of microorganisms isolated from wastewaters: Identification and evaluation of its potential for biosorption. Chemical Engineering Journal, 210: 325-332. http://dx.doi. org/10.1016/j.cej.2012.09.007

NELSON, D. L. \& COX, M. 2014. Princípios de bioquímica de Lehninger. Artmed: Porto Alegre, 1328 p.

NIES, D. H. 1999. Microbial heavy-metal resistance. Applied Microbiology and Biotechnology, 51 (6): 730-750. http://dx.doi. org/10.1007/s002530051457
PRESS, W. H.; TEUKOLSKY, S. A.; VETTERLING, W. T. \& FLANNERY, B. P. 2007. Numerical recipes: the art of scientific computing. Cambridge University Press: New York, 1235 p.

QUEIROZ, H. M.; NÓBREGA, G. N.; FERREIRA, T. O.; ALMEIDA, L. S.; ROMERO, T. B.; SANTAELLA, S. T.; BERNARDINO, A. F. \& OTERO, X. L. 2018. The Samarco mine tailing disaster: A possible time-bomb for heavy metals contamination? Science of The Total Environment, 637-638: 498-506. http://dx.doi.org/10.1016/j.scitotenv.2018.04.370

ROANE, T. M.; RENSING, C.; PEPPER, I. L. \& MAIER, R. M. 2009. Microorganisms and Metal Pollutants. In: PEPPER, I. L.; MAIER, R. M.; GERBA, C. P. (eds.). Environmental Microbiology. Elsevier, pp. 421-441. https://doi.org/10.1016/ B978-0-12-370519-8.00021-3

SALGADO, L. S.; ROSA, S. M. \& AZEVEDO, J. C. R. 2018. Concentrations of metals in liver of Guiana dolphins (Sotalia guianensis) from an estuary in Southeast of Brazil. Ecotoxicology and Environmental Contamination, 13 (1): 51-61. https://doi. org/10.5132/eec.2018.01.06

SANTOS, M. G.; CUNHA-SANTINO, M. B. \& BIANCHINI JR., I. 2009. Aerobic decomposition of Myriophyllum aquaticum (Vell.) Verdc. regulated by chemical composition of detritus and temperature. Acta Limnologica Brasiliensia, 21 (3): 269-276.

SANTOS, M. G.; CUNHA-SANTINO, M. B. DA \& BIANCHINI JR., I. 2011. Alterações espaciais e temporais de variáveis limnológicas do reservatório do Monjolinho (Campus da UFSCAR). Oecologia Australis, 15 (3): 682-696. https://doi. org/10.4257/oeco.2011.1503.18

SIGG, L. 1985. Metal transfer mechanisms in lake: the role of settling particles. In: STUMM, W. (ed.). New York: Chemical Processes in Lakes, pp. 283-310.

SILVA, R. H.; PANHOTA, R. S. \& BIANCHINI JR, I. 2011. Aerobic and anaerobic mineralization of Salvinia molesta and Myriophyllum aquaticum leachates from a tropical reservoir (Brazil). Acta Limnologica Brasiliensia, 23 (2): 109-118. https:// doi.org/10.1590/s2179-975x2011000200001

THOMAZ, S. M. \& CUNHA, E. R. 2010. The role of macrophytes in habitat structuring in aquatic ecosystems: methods of measurement, causes and consequences on animal assemblages'composition and biodiversity. Acta Limnologica Brasiliensia, 22 (2): 218-236. https://doi.org/10.4322/ actalb.02202011

THOMAZ, S. M.\& ESTEVES, F. A. 2011. Comunidade de Macrófitas Aquáticas. In: ESTEVES, F. DE A. (ed.). Fundamentos de Limnologia. Interciência: Rio de Janeiro, pp. 461-521.

VAlENTE, J. P. S.; PADIlHA, P. M. \& SilvA, A. M. M. 1997. Oxigênio dissolvido (OD), demanda bioquímica de oxigênio (DBO) e demanda química de oxigênio (DQO) como parâmetros de poluição no ribeirão Lavapés/Botucatu - SP. Eclética Química, 22: 49-66. http://dx.doi.org/10.1590/S010046701997000100005

VALLEE, B. L. \& ULMER, D. D. 1972. Biochemical effects of mercury, cadmium, and lead. Annual Review of Biochemistry, 41 (1): 91-128. https://doi.org/10.1146/annurev. bi.41.070172.000515

VIAROLI, P. \& CHRISTIAN, R. R. 2004. Description of trophic status, hyperautotrophy and dystrophy of a coastal lagoon through a potential oxygen production and consumption indexTOSI: Trophic Oxygen Status Index. Ecological Indicators, 3 (4): 237-250. https://doi.org/10.1016/j.ecolind.2003.11.001. 